\title{
MORPHOLOGICAL CHARACTERIZATION AND GENETIC DIVERSITY IN ORNAMENTAL SPECIMENS OF THE GENUS SANSEVIERIA ${ }^{1}$
}

\author{
MÉRCIA DE CARVALHO ALMEIDA RÊGO ${ }^{2}$, ANGELA CELIS DE ALMEIDA LOPES ${ }^{2}$, ROSELI FARIAS MELO DE \\ BARROS $^{3}$, ALONSO MOTA LAMAS ${ }^{4}$, MARCONES FERREIRA COSTA ${ }^{5 *}$, REGINA LUCIA FERREIRA-GOMES ${ }^{2}$
}

\begin{abstract}
The aim of this study was to characterize and estimate genetic divergence among twelve specimens of the Sansevieria genus from the collection of the Universidade Federal do Piauí (UFPI). A completely randomized experimental design was used with three replicates, and the plot consisted of four plants. In morphological characterization, qualitative and quantitative descriptors of leaves were evaluated. Genetic divergence among the specimens was determined by the Tocher clustering method and the hierarchical UPGMA. There is genetic variation among specimens evaluated, which was also expressed by the variability of colors, shapes, and sizes of the leaves. The Tocher clustering method and the hierarchical UPGMA were effective in differentiation of the specimens from multi-categorical qualitative descriptors, as the Tocher method grouped the accessions in two groups and the UPGMA in seven different groups. We highlight the accessions SSV 09 and SSV 10 as exhibiting the highest mean values in weekly leaf growth and in leaf height, important characteristics for local sale and for export.
\end{abstract}

Keywords: Germplasm collection. Genetic diversity. Ornamental plants.

\section{CARACTERIZAÇÃO MORFOLÓGICA E DIVERSIDADE GENÉTICA EM ESPÉCIMES ORNAMENTAIS DO GENERO SANSEVIERIA}

RESUMO - Este estudo teve como objetivo caracterizar e estimar a divergência genética entre doze espécimes do gênero Sansevieria da Coleção da Universidade Federal do Piauí (UFPI). Utilizou-se o delineamento experimental inteiramente ao acaso, com três repetições, sendo a parcela constituída por quatro plantas. Para caracterização morfológica foram avaliados descritores foliares de natureza qualitativa e quantitativa. A divergência genética entre os espécimes foi determinada pelos métodos de agrupamento de Tocher e o hierárquico UPGMA. Foi possível verificar que existe variação genética entre os indivíduos avaliados, em relação às cores, formatos e tamanhos das folhas. O método de agrupamento de Tocher e o método hierárquico UPGMA foram eficientes na diferenciação dos espécimes, a partir de descritores qualitativos multicategóricos, de modo que o método de Tocher reuniu os acessos em dois grupos e o UPGMA em sete grupos distintos. Destacamos os acessos SSV 09 e SSV 10 por apresentarem as maiores médias em crescimento foliar semanal e na altura da folha, características importantes para comercialização local e exportação.

Palavras-chave: Coleção de Germoplasma. Diversidade genética. Plantas ornamentais.

\footnotetext{
*Corresponding author

${ }^{1}$ Received for publication in $03 / 26 / 2020$; accepted in $09 / 03 / 2020$.

Extracted from the master's thesis of the first author.

${ }^{2}$ Department of Plant Science, Universidade Federal do Piauí, Teresina, PI, Brazil; merciarego@msn.com- ORCID: 0000-0002-5980-0673, acalopes@ufpi.edu.br - ORCID: 0000-0002-9546-5403, rlfgomes@ufpi.edu.br - ORCID: ORCID: 0000-0002-7700-6959.

${ }^{3}$ Department of Biology, Universidade Federal do Piauí, Teresina, PI, Brazil; rbarros.ufpi@gmail.com - ORCID: 0000-0001-9767-5546.

${ }^{4}$ Ministry of Agriculture, Cattle and Supplying, MAPA, Teresina, PI, Brazil; alonso.lamas@gmail.com - ORCID: 0000-0003-0555-9324.

${ }^{5}$ University Campus Amílcar Ferreira Sobral, Universidade Federal do Piauí, Floriano, PI, Brazil; marconescosta@ufpi.edu.br - ORCID: 0000-0001-8210-2673.
} 


\section{INTRODUCTION}

Ornamental plants are economically important for the horticulture industry, admired throughout the world, and valued for their aesthetic properties (MITROFANOVA; ZAKUBANSKIY; MITROFANOVA, 2018). The expansion of ornamental plants in the production sector, especially in Brazil, directly depends on the introduction of new items on the market. This basically occurs through plant breeding studies, with the creation of new cultivars or with the introduction and selection of new materials with favorable characteristics (BIONDI; LEAL, 2019; JUNQUEIRA; PEETZ, 2014; NASCIMENTO; GRAZIANO; LOPES, 2003).

Knowledge of the morphology, growth habit, and data regarding biology of species are of fundamental importance to define strategies in breeding programs. Such practices aim at creating conditions favorable to plant development, and visual quality is an important criterion for consumers that look for plants with immediate decorative effects (GARBEZ et al., 2017; OLIVEIRA et al., 2017).

Studies of characterization and evaluation of genetic diversity through morphological markers provide basis for breeding programs since they generate information related to distribution of diversity. This type of characterization should consider botanical descriptors of high heritability, easy measurement, and little genotype $\mathrm{x}$ environment interaction (COSTA et al., 2015; MELO et al., 2016).

The Sansevieria genus (Asparagaceae) includes a group of plants with ornamental foliage, valued for wide variety in the shape of their leaves. They are popularly known as mother-in-law's tongue, devil's tongue, jinn's tongue, bow string hemp, snake plant, and snake tongue. In addition to their aesthetic qualities, they are hardy plants, adapting to environments that are not always favorable to development of most plants (NASCIMENTO; GRAZIANO; LOPES, 2003; PÉREZ-LEÓN et al., 2015). It is a cosmopolitan genus, with Eastern Africa as its center of origin (NEWTON, 2018).

Their diversity in shape is quite surprising, ranging from miniscule plants, some with strong pointed leaves and others that are delicate and flat, up to formidable shrubs of 2 to 4 meters height. They are interesting plants recommended for urban landscaping due to their hardiness and characteristic shape of their leaves (BALDWIN; WEBB, 2016).

However, this genus has not been greatly studied, and it is necessary to generate basic knowledge regarding the species, such as taxonomy, morphology, the natural genetic variability that exists, and mode of propagation, important aspects for use in landscaping and floriculture.

The Universidade Federal do Piauí (UFPI) has a collection with twelve specimens of this genus. There is currently no study related to characterization and genetic divergence for the accessions of the collection. Investigation of the genetic resources available in the Germplasm bank is important to generate new products to meet the needs of the market. Based on this information, the aim of this study was to morphologically characterize and estimate the genetic diversity of the ex situ collection, as the information generated contributes to the pre-breeding of the species.

\section{MATERIAL AND METHODS}

The genetic material used consisted of twelve specimens from the ex situ collection of the Sansevieria genus of the Universidade Federal do Piauí (UFPI) (Table 1) at the Plant Science Department of the Centro de Ciências Agrárias in Teresina, PI, Brazil, at $05^{\circ} 05^{\prime} \mathrm{S}, 42^{\circ} 05^{\prime} \mathrm{W}$, and an altitude of $72.7 \mathrm{~m}$. A completely randomized experimental design was used, with three replicates, and each plot consisted of four plants.

In the absence of morphological descriptors defined for the Sansevieria genus, morphological characterization was based on characteristics described for the Sansevieria trifasciata Prain "Hahnii" species and vascular plants (GILMAN, 1999). The following qualitative leaf descriptors were evaluated: general shape of the lamina/leaf blade (GSL), shape of the base of the lamina/leaf blade (SBL), shape of the apex (SA), shape of the margin of the lamina/leaf blade (SML), shape of the leaf in transversal section (STS), type of venation (TV), leaf color (LC), color of leaf spots (CLS), color of the leaf margin (CLM), type of indumentum (TI), phyllotaxis (PHY), rhizome color (RC), and plant size (S, M, L). For plant size, small (S) was considered up to $25 \mathrm{~cm}$; medium (M), from 25 to 50 $\mathrm{cm}$; and large (L), greater than $50 \mathrm{~cm}$. The quantitative descriptors evaluated were as follows: width of the leaf base (WLB), width of the middle region of the leaf (WMRL), width of the leaf apex (WLA), and leaf height (LH).

In determination of leaf size, in $\mathrm{cm}$, a tape measure was used; and for widths of the base, middle region, and apical region, a digital caliper was used, in each example of the specimens characterized.

The rate of leaf growth of the widths of the base, middle region, and apex of the leaf and height of the leaf were measured in four examples of each specimen with the aid of a measuring tape over two months. Weekly growth of leaf height was determined in four examples of each specimen over seven weeks. 
M. C. A. RÊGO et al.

Table 1. Common name and botanical identification of the collection of the Sansevieria genus of UFPI. Teresina, PI, Brazil.

\begin{tabular}{|c|c|c|}
\hline Code & Common name & Species \\
\hline SSV 01 & Espada de São Jorge & Sansevieria sp. \\
\hline SSV 02 & Jacinto do Quênia & Sansevieria parva \\
\hline SSV 03 & Espadinha & Sansevieria sp. \\
\hline SSV 04 & Espadinha & Sansevieria sp. \\
\hline SSV 05 & Espadinha & Sansevieria trifasciata \\
\hline SSV 06 & Espadinha verde e amarelo & Sansevieria trifasciata \\
\hline SSV 07 & Espada de São Jorge & Sansevieria sp. \\
\hline SSV 08 & $\begin{array}{l}\text { Lança de São Jorge, } \\
\text { Flecha de Î́ndio }\end{array}$ & Sansevieria cyilindrica \\
\hline SSV 09 & Lança de São Jorge & Sansevieria masoniana \\
\hline SSV 10 & Mason do Congo & Sansevieria zanzibarica \\
\hline SSV 11 & $\begin{array}{l}\text { Língua de Sogra, } \\
\text { Rabo de Lagarto }\end{array}$ & Sansevieria trifasciata \\
\hline SSV 12 & Espada de São Jorge & Sansevieria trifasciata var. laurenti \\
\hline
\end{tabular}

Comparison between the mean values of the specimens, the Scott-Knott clustering criteria at 5\% probability was used. Genetic divergence among the specimens was determined by the Tocher cluster method and the hierarchical UPGMA (Unweighted Pair Group Method with Arithmetic Mean). In these analyses, the Genes 2013.5.1 program was used (CRUZ, 2016).

\section{RESULTS AND DISCUSSION}

The twelve specimens from the collection of the Sansevieria genus of UFPI were morphologically characterized, exhibiting variation for color, shape, and arrangement of the leaves (Table 2), except in regard to the general shape of the lamina/leaf blade, shape of the base of the lamina/leaf blade, shape of the margin of the lamina/leaf blade, type of venation, type of leaf indumentum, and root color - in that respect, the leaves are $100 \%$ lanceolate, cuneate, with the margin of the lamina/leaf blade whole, with parallel venation, and glabrous, and the root is orange colored. Some studies related to the economic importance of Sansevieria worldwide in horticulture, where many species are grown in pots and gardens as ornamental plants (TAKAWIRA-NYENYA et al., 2014).

Considering the shape of the apex of the lamina/leaf blade, $83 \%$ have a caudate apex, and $17 \%$, acuminate. Regarding the shape of the leaf in transversal section, $83 \%$ have an elliptical shape, $17 \%$, a cylindrical shape.

A dark green leaf color with light green spots is borne by $58 \%$ of the specimens; $25 \%$ have an inverse combination, and variegated leaves with dark green spots appear in $17 \%$ of the total. A margin of green color characterizes $75 \%$ of the specimens, and $25 \%$ of orange color. Generally leaves vary regarding color; colors are initially brighter and margins are concave, but as leaves age, they become yellowed and convex. In some plants, when they reach the adult phase, the bases of the leaves become more attenuated and the spots on the leaves become darker. 
Table 2. Morphological descriptors ${ }^{1}$ : shape of the apex (SA), shape of the leaf in the transversal section (STS), leaf color (LC), color of leaf spots (CLS), color of leaf margin (CLM), phyllotaxis (PHY), rhizome color (RC), and plant size (PS), evaluated in twelve specimens of Sansevieria, in the municipality of Teresina, PI, Brazil.

\begin{tabular}{cllllllll}
\hline Specimen & SA & STS & LC & CLS & CLM & PHY & RC & PS \\
\hline SSV 01 & CA & EL & DG & LG & G & RS & O & M \\
SSV 02 & CA & EL & DG & LG & O & RS & O & M \\
SSV 03 & CA & EL & LG & DG & G & RS & O & S \\
SSV 04 & CA & EL & LG & DG & G & RS & O & S \\
SSV 05 & CA & EL & DG & LG & G & RS & O & S \\
SSV 06 & CA & EL & VG & DG & G & RS & O & S \\
SSV 07 & CA & EL & DG & LG & G & RS & O & M \\
SSV 08 & AC & CL & LG & DG & $*$ & EQ & BG & L \\
SSV 09 & CA & EL & DG & LG & O & RS & O & L \\
SSV 10 & AC & CL & DG & LG & $*$ & RS & BG & L \\
SSV 11 & CA & EL & DG & LG & G & RS & O & L \\
SSV 12 & CA & EL & VG & DG & G & RS & O & L \\
\hline
\end{tabular}

${ }^{1}$ AC - Acuminate, CA - Caudate; CL - Cylindrical, EL - Elliptical; LG - Light Green, DG - Dark Green, VG Variegated; O - Orange, G - Green; EQ - Equitant, RS - Rosulate; BG - Beige; S - Small, M - Medium, L - Large.* Specimen without margin.

In regard to phyllotaxis, $92 \%$ are rosulate and $8 \%$, equitant. An orange colored rhizome occurs in $83 \%$ and beige rhizome in $7 \%$. For plant size, $25 \%$ are medium, $33 \%$ are small, and $42 \%$ are large. According Baldwin and Webb (2016), the phenotypic variation observed in the Sansevieria genus for leaf morphology may be the result of phylogenetic inheritance or ecological adaptation.

For the quantitative descriptors of the leaf, a significant difference $(P<0.05)$ is observed among the specimens of Sansevieria characterized, indicating the existence of genetic variability (Table 3).

Table 3. Mean values of the quantitative descriptors of the leaf: width of the leaf base (WLB), width of the middle region of the leaf (WMRL), width of the leaf apex (WLA), and leaf height (LH), evaluated in twelve specimens of the Sansevieria genus in the municipality of Teresina, PI, Brazil.

\begin{tabular}{ccccc}
\hline Specimen & WLB $(\mathrm{mm})$ & WMRL $(\mathrm{mm})$ & WLA $(\mathrm{mm})$ & LH $(\mathrm{cm})$ \\
\hline SSV 01 & $14.80 \mathrm{~B}$ & $53.26 \mathrm{~B}$ & $6.09 \mathrm{~A}$ & $22.87 \mathrm{D}$ \\
SSV 02 & $12.56 \mathrm{~B}$ & $16.72 \mathrm{D}$ & $3.94 \mathrm{~A}$ & $29.28 \mathrm{D}$ \\
SSV 03 & $11.75 \mathrm{~B}$ & $28.22 \mathrm{C}$ & $1.25 \mathrm{~B}$ & $9.82 \mathrm{E}$ \\
SSV 04 & $19.58 \mathrm{~A}$ & $37.43 \mathrm{C}$ & $4.04 \mathrm{~A}$ & $11.90 \mathrm{E}$ \\
SSV 05 & $18.36 \mathrm{~A}$ & $47.40 \mathrm{~B}$ & $4.04 \mathrm{~A}$ & $12.08 \mathrm{E}$ \\
SSV 06 & $10.95 \mathrm{~B}$ & $34.46 \mathrm{C}$ & $3.40 \mathrm{~A}$ & $8.59 \mathrm{E}$ \\
SSV 07 & $10.18 \mathrm{~B}$ & $30.97 \mathrm{C}$ & $3.67 \mathrm{~A}$ & $31.99 \mathrm{D}$ \\
SSV 08 & $21.21 \mathrm{~A}$ & $19.01 \mathrm{D}$ & $3.52 \mathrm{~A}$ & $71.25 \mathrm{~B}$ \\
SSV 09 & $19.69 \mathrm{~A}$ & $83.67 \mathrm{~A}$ & $4.26 \mathrm{~A}$ & $77.93 \mathrm{~A}$ \\
SSV 10 & $21.47 \mathrm{~A}$ & $16.10 \mathrm{D}$ & $3.77 \mathrm{~A}$ & $54.61 \mathrm{C}$ \\
SSV 11 & $21.70 \mathrm{~A}$ & $48.67 \mathrm{~B}$ & $3.65 \mathrm{~A}$ & $67.58 \mathrm{~B}$ \\
SSV 12 & $24.96 \mathrm{~A}$ & $53.19 \mathrm{~B}$ & $2.64 \mathrm{~A}$ & $80.27 \mathrm{~A}$ \\
\hline
\end{tabular}

Mean values followed by the same letter in the column do not differ from each other by the Scott-Knott test at $5 \%$ probability.

The width of the leaf base, with variation from $10.18 \mathrm{~mm}$ (SSV 07) to $24.96 \mathrm{~mm}$ (SSV 12), formed two groups, showing little contribution to divergence among the specimens. For the middle region of the leaves, four groups were formed, with a higher mean value for SSV $09(83.67 \mathrm{~mm})$, whose leaves are quite attractive for their width, and lower mean values for SSV $08(19.01 \mathrm{~mm})$, SSV 02 
(16.72 $\mathrm{mm})$, and SSV $10(16.10 \mathrm{~mm})$. Regarding the width of the apex, the variation was from $1.25 \mathrm{~mm}$ (SSV 03) to $6.09 \mathrm{~mm}$ (SSV 01), forming two groups.

Knowledge of the leaf height of Sansevierias represents an initial reference for establishing parks and gardens, as well as for production of species used for manufacturing fibers. For leaf height, five groups were formed. The specimens SSV 09 and SSV 12 are of greater size, $77.93 \mathrm{~cm}$ and $80.27 \mathrm{~cm}$, respectively. Lower mean values were observed for SSV 06 (8.59 cm), SSV $03(9.82 \mathrm{~cm})$, SSV 04 (11.90 $\mathrm{cm})$, and SSV $05(12.08 \mathrm{~cm})$, commonly called "little swords" or "dwarf swords". The species Sansevieria trifasciata has up to 6 leaves per rosette. In addition, most of the commercially important cultivars in Florida were selected from Sansevieria trifasciata (FRANCK, 2012).

The observations made regarding weekly leaf growth in height show that the specimens SSV 09 and SSV 10 grew more quickly, arriving at a mean increase greater than $5 \mathrm{~cm}$ per week, which may be an advantage in systems of multiplication for local commercialization and/or export, considering that this character is the most relevant to the pre-breeding crop, since it has a direct relationship with the quantity and quality of the leaf fiber. The Sansevierias SSV 02, SSV 03, SSV 04, SSV 05, and SSV 06, which are dwarf varieties, except for SSV 02 , obtained the lowest mean values for leaf growth (Table 4).

Additional knowledge of species of Sansevieria that can be successfully cultivated as ornamentals reported here widens the knowledge on the range of genetic resources that can be potentially exploited commercially. Thus, specimens SSV 09 and SSV 10 are indicated for crop breeding programs. The identification of a certain accession with potential to be used as potted plant, or for landscape plants, foliage or even as ornamental minifruits depends on the set of characteristics related to each of these categories. Besides, these accessions may be potential parents in breeding programs for the generation of hybrids with the desired characteristics, even without having all the desirable characteristics for a certain use.

Table 4. Weekly record of growth in leaf height of Sansevieria sp. in Teresina, PI, Brazil.

\begin{tabular}{ccc}
\hline Specimen & Mean growth (cm) & Maximum (cm) \\
\hline SSV 01 & 1.19 & 3.70 \\
SSV 02 & 0.86 & 6.00 \\
SSV 03 & 0.89 & 6.10 \\
SSV 04 & 0.79 & 6.00 \\
SSV 05 & 0.43 & 5.50 \\
SSV 06 & 0.65 & 6.30 \\
SSV 07 & 1.88 & 4.60 \\
SSV 08 & 1.60 & 11.10 \\
SSV 09 & 5.49 & 15.20 \\
SSV 10 & 5.54 & 12.00 \\
SSV 11 & 2.73 & 21.30 \\
SSV 12 & 2.71 & 8.80 \\
\hline
\end{tabular}

Different methods of multivariate analysis use morphological variations of plants in estimation of genetic divergence, and among them are clustering methods. The use of multivariate techniques allows evaluation of genetic material from a set of characteristics considering the importance of each variable in the total variation (COSTA et al., 2016; MENEGATTI et al., 2017). Thus, knowledge about similarity and dissimilarity may contribute to the rational planning of genetic breeding programs and optimization of the management of the preserved germplasm, which contributed to the knowledge of the phenotypic variation and divergence patterns of the species (FIGÁS et al., 2018).

Seven groups were formed using data of leaf qualitative descriptors (WLB, WMRL, WLA and
LH) by the hierarchical UPGMA method, based on the average Euclidean distance (Figure 1). The cophenetic correlation coefficient of the dendrogram $(\mathrm{r}=0.839)$ revealed good fit between the graphic representation of the distances and its original matrix (ROHLF; FISHER, 1968).

Based on the dissimilarity matrix, it can be observed that the accessions that showed the highest dissimilarity were SSV 09 and SS V03 (D = 2.57). Dissimilarity between different individuals was mostly found with respect to genotype SSV 09 mainly because it has wide and tall leaves. The genotype SSV 12 also revealed a large genetic dissimilarity in relation to the others, due to the features width of the base, width of the leaf apex and leaf height. 
M. C. A. RÊGO et al.

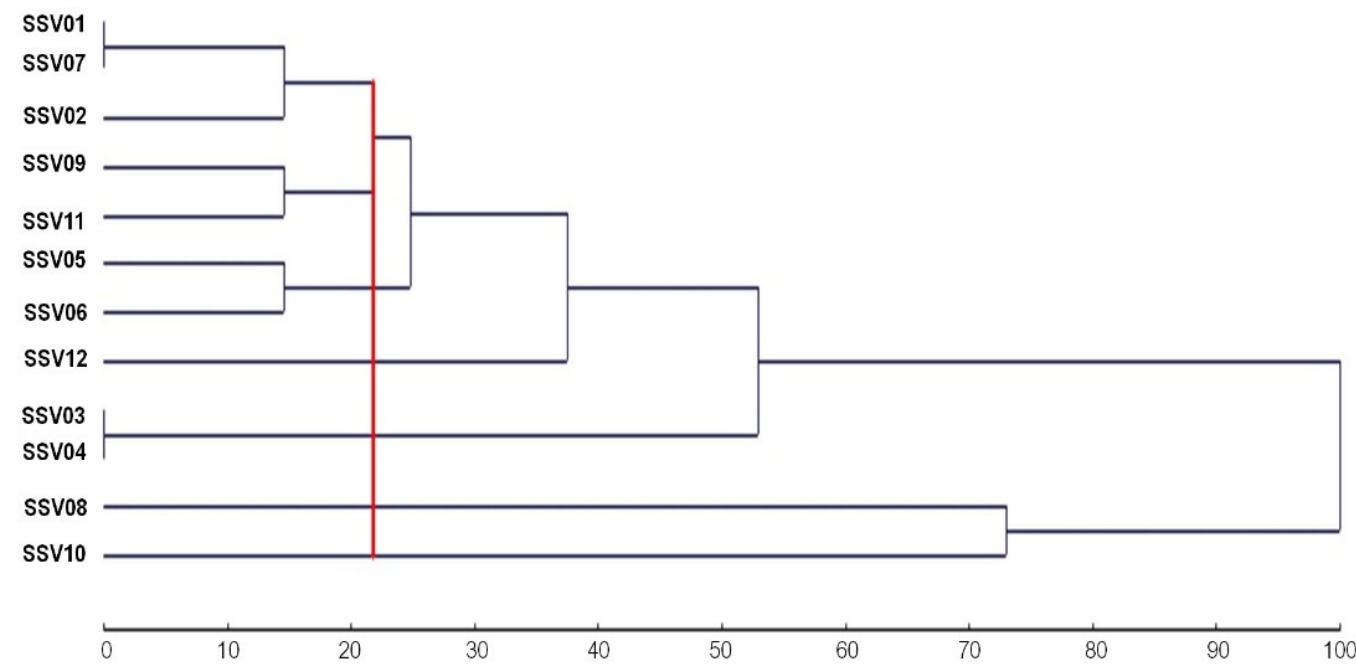

Figure 1. Dendrogram of genetic dissimilarity among twelve specimens of the genus Sansevieria, obtained by the hierarchical UPGMA. Teresina, PI, Brazil.

Group I contained the accessions SSV 01, SSV 07, and SSV 02, which were similar in relation to the following characteristics: leaf color, leaf spot color, and plant size. Group II consisted of the specimens SSV 09 (Sansevieria trifasciata) and SSV 11 (Sansevieria masoniana), which had thirteen descriptors in common, differing only in relation to the color of the leaf margin.

Group III had Sansevierias of green and green and yellow color and small size (SSV 05 and SSV 06). The SSV 06 specimen, also known as "little sword", is a chimera of SSV 05 . When reproduced by tillers, its leaves have characteristics identical to those of the original plant, but if it is reproduced by leaf cuttings, the new plant will have characteristics of the specimen SSV 05 since the chimeric form tends to return to its original form.

Group IV is represented by SSV 12 (Sansevieria trifasciata var. laurentii), characterized by green and yellow leaf color and by large size of the plant. The specimens SSV 03 and SSV 04 are identical, with light green leaf color and small size, and were placed in Group V.

Group VI, formed by SSV 08, plant with cylindrical leaves, beige rhizome color, large size, and light green leaf color. Group VII, represented by SSV 10, has cylindrical leaves, beige rhizome color, large size, and dark green leaves. Analysis of the results obtained, through characterization of the Sansevierias, shows that the accessions vary greatly regarding their leaves, from short, fleshy, thick leaves to long, narrow, leathery ones.

Santos (2014) evaluated the genetic dissimilarity between accessions of the Agave genus conserved in the EMBRAPA Cotton germplasm bank by UPGMA method and observed the formation of groups 4 , in which group I was the largest, comprising $51.35 \%$ of the accessions. The variables that had the most contribution to these groups formation were leaf color and number of leaves. Moreover, Carneiro (2017) characterized sisal accessions from quantitative traits and observed the formation of two groups by UPGMA method, indicating that, although there is phenotypic diversity, the results may be indicative of a narrow genetic basis among individuals. The Tocher optimization method is normally used concomitantly with the UPGMA hierarchical method, providing correspondence for the allocation of elements in the clusters (CANTELLI et al., 2016). In cluster analysis of the specimens by the Tocher method, two groups were observed (Table 5).

The study of divergence performed by Tocher cluster analysis grouped the accessions through analysis of the descriptors evaluated in such a way that there was greater homogeneity within the group and a higher level of heterogeneity among the groups (CRUZ; REGAZZI; CARNEIRO, 2013; ROSA et al., 2019). Group I was formed by eight accessions that were similar in relation to the shape of the apex (caudate), shape of the leaf in the transversal section (elliptical), and rhizome color (orange). Included in this group were the specimens SSV 03, SSV 04, SSV 05, and SSV 06, known as "Little Swords", since they had linear, whole, small leaves. Group II contained the specimens SSV 08 and SSV 10, the popular "St. George's Lance", plants that have leaves in the shape of lances. This group is also characterized by beige colored rhizomes.

In this is study the UPGMA and Tocher methods demonstrated that the clusters in the dendrograms could be used for identification of the method yielding the highest number of clusters and, consequently, constitute an improvement in the possibility of selecting the most divergent parents. 
M. C. A. RÊGO et al.

Table 5. Groups of the specimens of Sansevieria sp., established by the Tocher method, using the dissimilarity matrix. Teresina, PI, Brazil.

\begin{tabular}{cc}
\hline Group & Specimens \\
\hline I & SSV 01, SSV 07, SSV 02, SSV 05, SSV 11, SSV 09, SSV 06, SSV 12, SSV 03, SSV 04 \\
II & SSV 08, SSV 10 \\
\hline
\end{tabular}

For commercialization of the Sansevieria genus to increase in the ornamental market, the types of varieties must increase. In this perspective, morphological characterization and establishment of genetic distance among the plants constitute important contributions to the choice of divergent and complementary plants for the development of segregating populations in plant breeding programs, with the aim of diversifying the ornamental market. Therefore, the characterization of these accessions is crucial to identify the ornamental potential of the collection. This study of Sansevieria germplasm provides important data on the accessions evaluated, highlighting the relevance of maintaining an active germplasm bank, in which the genetic variation of certain species can be used for different purposes.

\section{CONCLUSION}

The application of morphological descriptors to characterize selected accessions of Sansevieria revealed variation of the active germplasm bank and allowed the identification of accessions SSV 09 and SSV 10 with ornamental potential, as the most advantageous in systems of multiplication for local commercialization and export, since they had the highest mean values in relation to weekly leaf growth and plant height, aggregating value to the germplasm preserved. The Tocher cluster method and the hierarchical UPGMA were effective in estimating the genetic differentiation of the accessions; the Tocher method grouped them in two groups and the UPGMA, in seven different groups.

\section{ACKNOWLEDGMENTS}

The authors would like to thank the Coordination for the Improvement of Higher Education (CAPES) for the scholarships granted and its assistance.

\section{REFERENCES}

BALDWIN, A. S.; WEBB, R. H. The genus Sansevieria: An introduction to molecular (DNA) analysis and preliminary insights to intrageneric relationships. Sansevieria, 34: 14-26, 2016.
BIONDI, D.; LEAL, L. Caracterização das plantas produzidas no Horto Municipal da BarreirinhaCuritiba/PR. Revista da Sociedade Brasileira de Arborização Urbana, 3: 20-36, 2019.

CANTELLI, D. A. V. et al. Analysis of the genetic divergence of soybean lines through hierarchical and Tocher optimization methods. Genetics and Molecular Research, 15: 1-13, 2016.

CARNEIRO, J. L. S. Caracterização acessos de sisal usando descritores da planta e da fibra. 2016. 117 f. Tese (Doutorado em Agronomia: Área de Concentração em Recursos Genéticos Vegetais) Universidade Estadual de Feira de Santana, UEFS, Feira de Santana, 2017.

COSTA, L. V. et al. Caracterização morfológica de acessos de pimentas do Amazonas. Horticultura Brasileira, 33: 290-298, 2015.

COSTA, M. F. et al. Characterization and Genetic Divergence of Casearia grandiflora Populations in the Cerrado of Piaui State, Brazil. Floresta e Ambiente, 23: 387-396, 2016.

CRUZ, C. D.; REGAZZI, A. J.; CARNEIRO, P. C. $\mathrm{S}$. Modelos biométricos aplicados ao melhoramento genético. 4.ed. Viçosa, MG: UFV, 2013. 514 p.

CRUZ, C. D. Genes Software-extended and integrated with the R, Matlab and Selegen. Acta Scientiarum Agronomy, 38: 547- 552, 2016.

FIGÁS, M. R. et al. Variation of morphological descriptors for the evaluation of tomato germplasm and their stability across different growing conditions. Scientia Horticulturae, 238: 107-115, 2018 .

FRANCK, A. R. Guide to agave, cinnamomum, corymbia, eucalyptus, pandanus, and sansevieria in the flora of Florida. 2012. Disponível em: $<$ https://scholarcommons.usf.edu/bcm_facpub/6/>. Acesso em: 10 jul. de 2020.

GARBEZ, M. et al. Ornamental plants architectural characteristics in relation to visual sensory attributes: a new approach on the rose bush for objective evaluation of the visual quality. European Journal 
of Horticultural Science, 83: 87-201, 2017.

GILMAN, E. F. Sansevieria trifasciata Hahnii. Cooperative Extension Service. 1 ed. University of Florida, USA: Fact Sheet FPS, 1999. 534 p.

JUNQUEIRA, A. H; PEETZ, M. S. O setor produtivo de flores e plantas ornamentais do Brasil, no período de 2008 a 2013: atualizações, balanços e perspectivas. Revista Brasileira de Horticultura Ornamental, 20: 115-120, 2014.

MELO, C. A. F. et al. Morphological characterization and genetic parameter estimation in backcrossed progenies of Passiflora L. for ornamental use. Scientia Horticulturae, 212: 91$103,2016$.

MENEGATTI, R. D. et al. Genetic divergence among provenances of Mimosa scabrella Benth. based on seed analysis. Revista Brasileira de Ciências Agrárias, 12: 366-371, 2017.

MITROFANOVA, I. V.; ZAKUBANSKIY, A. V.; MITROFANOVA, O. V. Viruses infecting main ornamental plants: an overview. Ornamental Horticulture, 24: 95-102, 2018.

NASCIMENTO, T. M; GRAZIANO, T. T.; LOPES, C. S. Espécies e cultivares de sansevierias como planta ornamental. Revista Brasileira de Horticultura Ornamental, 9: 111-119, 2003.

NEWTON, L. E. Conservation of Sansevierias in Kenya. 2018. Disponível em: < https:// www.sansevieria.lima-city.de/gb/so2018_1_1218.pdf $>$. Acesso em: 15 out. 2018.

OLIVEIRA, C. D. C. et al. Riqueza de mudas de espécies florestais nativas potencialmente produzidas na Bacia do Rio Grande, MG. Pesquisa Florestal Brasileira, 37: 159-170, 2017.

PÉREZ-LEÓN, G. et al. Chemical control of anthrachnose of Sansevieria trisfasciata var. Hahnii on a detached-leaf system. Agronomía Mesoamericana, 26: 305-313, 2015.

ROHLF, F. J.; FISHER, D. R. Tests for hierarchical structure in random data sets. Systematic Biology, 17: 407-412, 1968.

ROSA, T. L .M et al. Biometry and genetic diversity of paradise nut genotypes (Lecythidaceae). Pesquisa Agropecuária Brasileira, 54, e00240, 2019.

SANTOS, K. S. Estudo genético e citogenético em espécies de do gênero Agave (Agavaceae). 2014.
83 f. Dissertação (Mestrado em Agronomia: Área de Concentração em Recursos Genéticos Vegetais) Universidade Estadual de Feira de Santana, UEFS, Feira de Santana, 2014.

TAKAWIRA-NYENYA, R. et al. Ethnobotanical Uses of Sansevieria Thunb (Asparagaceae) in Coast Province of Kenya. Ethnobotany Research \& Applications, 12: 51-69, 2014. 